\title{
支援的他者の存在が心臟血管反応に与える影響
}

\author{
早稲田大学 医療行動科学研究所 \\ 長野 祐一郎 ${ }^{1)}$ \\ 早稲田大学 人間科学部 \\ 巟玉 昌久
}

\section{The effect of a supportive other on cardiovascular responses}

\author{
Yuichiro NAGANO \\ Institute of Medico-Behavioral Science, Waseda University, \\ 2-579-15, Mikajima, Tokorozawa, Saitama 359-1192, Japan \\ Masahisa KoDAma \\ School of Human Sciences, Waseda University, \\ 2-579-15, Mikajima, Tokorozawa, Saitama 359-1192, Japan
}

The effects of the presence of a supportive other on hemodynamics were assessed in 28 male undergraduate students. Participants were assigned to a support group or to a non-support group and they executed a mental arithmetic task. In the support group, a close friend accompanied participants to the laboratory and they executed the task in the proximity of the friend. To minimize evaluative aspects, friends executed their own task (cross word puzzle) while listening to music with headphones. Heart rate, blood pressure, impedance cardiography and emotional responses were recorded. Participants in the support group relative to the non-support group showed reduced reactivity only in diastolic blood pressure. Distinct differences in hemodynamics were not found between the two groups. There were no group differences in negative affects, but obvious differences were found in positive affects. Interpersonal support may reduce cardiovascular response through cognitive processes. The role of positive affects was particularly emphasized as a stress buffer process. (Japanese Journal of Physiological Psychology and Psychophysiology, 23(3) : 197-205, 2005.)

Key words: Cardiovascular reactivity, support, hemodynamics

2004.8.20 受稿, 2005.7.26 受理

1）現所属：文京学院大学人間学部 
【要 約】支援的他者の存在が，血行動態に与える影響が 28 名の男子大学生を用い検討された。被験者は, サポート群と非サポート群に分けられ, 暗算課題を行った。サポート群の被験者は親しい友人を同伴し, 友 人と一緒に課題を行った。評価的側面を最小化するため, 友人はへッドフォンで音楽を聴きながら自分の課 題（クロスワードパズル）を行った。 心拍数, 血圧, インピーダンスカーディオグラフィ, 感情反応が記録 された。非サポート群に比ベサポート群の被験者は, 拡張期血圧においての夕, 反応性の減少を示した。両 群の血行動態の間に, 明確な差は認められなかつた. 否定的感情に関しては, 両群に差は見られなかったが, 肯定的感情に関しては両群に明確な差が認められた。対人的なサポートは, 認知的なプロセスを通じて心臟 血管反応を軽減するものと思われる。 ストレスバッファプロセスにおける肯定的感情の役割の重要性が特に 強調された。

\section{はじめに}

本研究は, 対人関係によるストレス軽減効果に着 目し，支援的他者の存在が暗算ストレス負荷時の心 臟血管反応に与える影響を, その生理的, 心理的媒 介過程を考慮に入れ，検討したものである.

ストレス下における心臟血管反応の説明を試み たモデルとしては，外界への注意に注目したLacey グループの環境の取り入れ/拒否モデル (Lacey \& Lacey, 1974), コントロールに注目した Obristグルー プの能動/受動的対処モデル (Obrist, 1981), 認知的 評価に注目した Blascovich グループの挑戦/脅威モ デル (Blascovich \& Mendes, 2000) などがある. しか し, これらのモデルはいずれも被験者が単独でスト レス状況におかれる事を想定したものであり, 対人 要因の影響をほとんど考慮していない.しかし, 日 常ストレスの多くが対人的なものであること（Bolger, DeLongis, Kesseler, \& Schilling, 1989), 対人要因が心 臟血管系に無視できない顕著な影響を与えうること (長野, 2005; Smith, Nealey, Kircher, \& Limon, 1997; Wright, Dill, Geen, \& Anderson, 1998）を考えると, 今後はこれらをべースに, 対人要因まで考慮に入れ たモデルを構築していく事が重要であると言えるだ ろう。近年の心臓血管系精神生理学は, 心臓血管反 応性の個人差に注目しすぎる傾向があり，そのよう なリスク要因を発現させ疾患にまで発展させる, 状 況要因の重要性を見過ごしてきたと指摘されている (Carroll \& Sheffield, 1998; Smith \& Gerin, 1998). そ こで, 心臓血管系疾患を誘発する状況要因のうち, 最も重要と考えられる対人ストレス場面への興味が 高まりつつある (Kamarck \& Lovallo, 2003; Linden, Rutledge, \& Con, 1998; Schwartz, Gerin, Davidson, Pickering, Brosschot, Thayer, Christenfeld, \& Linden,
2003; Waldstein, Neumann, Burns, \& Maier, 1998).

我々は日常生活で対人関係に起因するストレスを 数多く経験するが，その一方でそのようなストレス をやはり対人関係により解消しているものと思われ る.したがって, ストレス負荷過程だけでなく，そ の軽減過程においても対人要因は重要な役割を果し ていると言えよう. 疫学的研究では, 社会的要因が 身体に与える影響が広く検討され, 社会関係の欠如 はあらゆる原因による死亡率, 罹患率を高める事が 示されてきた (House, Landis, \& Umberson, 1988; House, Robbins, \& Metzner, 1982). それらの中でも社会的な 結びつきが, 冠状動脈性心臟疾患の発生を減少させ るとの報告 (Blumenthal, Burg, Barefoot, Williams, Haney, \& Zimet, 1987; Seeman \& Syme, 1987）は非常 に興味深い.しかし, これらの疫学的研究は相関研 究を基本としており, その方法論上の制約から, 社 会的な結びつきと健康の相関を示す事はできるが, その因果関係を説明する事が難しい (Christenfeld \& Gerin, 2000). たとえば，健康な人間は魅力的である ために社会的な相互作用が必然的に多くなる，と いうような可能性を否定する事ができない. また, 社会的な結びつき (social affiliationもしくは social integration）が健康を増進するとしても，その背景に どのようなシステムが存在するのか, すなわち、そ の媒介過程を知ることが困難である点も問題である.

これらの課題を克服するには, 社会的結びつきが 健康に与える影響の実験的検討が必須である。 その ような点で, ソーシャルサポート心蔵血管反応性仮 説 (Lepore, 1998; Uchino, Cacioppo, \& Kiecolt-Glaser, 1996) に基づく研究報告からは, 大変興味深い知見 が得られていると言えよう.ソーシャルサポート心 臓血管反応性仮説では, 親しい他者の存在が急性又 
長野・児玉：支援的他者と心臟血管反応

トレス負荷時の心臓血管反応を軽減し，その繰り返 しにより心蔵血管系疾患の発生が抑制されると考え る. Kamarck, Manuck, \& Jennings (1990) の研究に端 を発するこれらの研究は, 暗算課題, 鏡映描写課題, 概念構成課題, ディベートなど様々な状況で, 友人 の存在がストレス反応を軽減しうる事を示してきた (Allen, Blascovich, \& Mendes, 2002; Allen, Blascovich, Tomaka, \& Kelsey, 1991; Edens, Larkin, \& Abel, 1992; Gerin, Pieper, Levy, \& Pickering, 1992; Kamarck, Annunziato, \& Amateau, 1995; Kors, Linden, \& Gerin, 1997; Lepore, Allen, \& Evans, 1993). いくつかの例外 はあるものの, 支援的な他者の存在が，急性ストレ 又刺激に対する心臟血管反応を軽減するという結果 は，心臓血管系精神生理学において確固たる事実と して受け入れられつつある.

一方，先に指摘した媒介過程が明確でないという 問題点は, ソーシャルサポート心臟血管反応性仮説 に関してもそのまま当てはまる. 支援的他者の存在 が心臓血管系に生じるストレス反応を軽減する事は 確かめられたものの, その背景となる媒介過程は, ほとんど解明されていない。，心理的な媒介過程の検 討としては，ストレス反応軽減効果が生じる際の主 観的感情変化の調査が考えられるが, 興味深い事に 多くの研究が, 支援的他者の存在は, 主観的ストレ スや不快感情に影響を与えない事を報告している (Lepore, 1998).このような結果に対し Kamarck et al. (1990) は支援的他者の存在は主観的感情変化を介さ ず，より直接的に心臟血管反応に影響すると考察し た.しかし，これらの結果に対しLepore (1998)は, 調査に用いられた質問紙の妥当性が十分でない事, ぞの研究も否定的感情のみを調べており肯定的感情 の増大によりストレス反応軽減効果が生じる可能性 を無視している事を指摘した。したがつて心理的媒 介過程の検討には, 妥当性が十分に検討されており, 否定的感情だけでなく肯定的感情も検討可能な質問 紙の適用が必要と考えられる。

一方，心臓血管系精神生理学ではインピーダンス カーディオグラフィによる血行力学的反応の検討が 一般的になっているが, ソーシャルサポート心臟血 管反応性仮説に関する研究に適用例が存在しない事 は大きな問題である. Williams（1986）に指摘される ように，ストレス下における心臟血管反応は, 心臟
型と血管型の二つのパタンに大別され, 心臟血管系 精神生理学では, 血圧の変化だけでなく, その背景 となる血行力学的反応パタンに注目してきた。 他者 の存在によりもたらされるストレス負荷時の心臓血 管反応の軽減が, ぞのような血行力学的反応変化に より生じるかを明らかにする事は, サポート効果の 生理学的媒介過程解明の第一歩であり, そこから得 られる知見は，ぞのような神経調節によりその反応 が実現されているのか，また環境適応的にどのよう な場面を意識した反応なのかを推測する上で, 重要 なてがかりとなる事が期待される.

本研究では, 支援的他者の存在が暗算負荷時の心 臓血管反応に与える影響を検討する。 その際，心理 的媒介過程を検討するために, 支援的他者の存在が 暗算課題中の主観的感情変化に与える影響を検討す る. 心理指標は, 否定的肯定的, 双方の感情語を含 む点, 生理的反応との整合性が期待できる点から, 畑山・Antonides・松岡・丸山 (1994)による GACL を用いる事とする。.また, 生理学的媒介過程を検討 するために，インピーダンスカーディオグラフィを 導入し, 支援的他者の存在が暗算課題中の血行力学 的反応に与える影響の検討を行う.

\section{方 法}

\section{被験者}

被験者は男子大学生 28 名（平均年齢 20.4, $S D=1.3$ ) であり，心臟血管系に障害がある者は含まれなかつ た. 半数は単独で実験に参加するサポートなし群に, 残りの半数は友人と一緒に実験に参加するサポート あり群に割り当てられた。勧誘時に, サポート群の 被験者には, 同性の友人を一人同伴して実験に参加 するように伝えた。被験者，友人に対し，約 1 時間 の実験参加に対する謝礼として 1500 円を支払った。

\section{手続き}

被験者は実験室に入室した後, 実験手続きの説明 を受け，電極を装着した。両群ともに 4 分間の安静 期の後に，4 分間の暗算課題を行った。サポートな し群の被験者は, 安静期, 課題期を通じて単独で害 験に参加した。 サポートあり群の被験者は, 安静期, 課題期を通じて友人とともに実験に参加した.

被験者はシールドルームの中でリクライニングチ エアーに腰掛け実験に参加した。他者による評価的 
観察は心藏血管反応をむしろ増大させる事が知られ ている (Smith et al., 1997; Wright et al., 1998). そこ で Kamarck et al. (1990)を参考にし，評価的側面を 最小限にするため, 友人は被験者の課題遂行が目に 留まらぬように, 被験者の右側に 90 度の角度で配 置された椅子に座り，さらに実験期間を通じてへッ ドフォンで音楽を聴きながらクロスワードパズルを 行い続けた。被験者には, 友人はサポート役として 実験に参加し, 被験者の課題遂行を観察したり評価 したりする事が不可能な状態である事を説明した。 また, 友人は被験者の静かなサポート役として実験 に参加するよう教示を行った.

課題は暗算課題を用いた。暗算課題は，正誤のフ イードバックがないと動機づけが下がり，十分な課 題負荷が得られない場合が多い。また，コンピュー タディスプレイを介した課題提示は, 画面に対する 強い注意を喚起する事から，迷走神経活動の京進を 招き, 暗算以外の効果が心臓血管反応に混入しやす い(長野, 2002)。これらの事実を踏まえ，暗算課題 は2378から 7 ずつ減算し続け, その結果を声に出 して報告する形式を用いた。その際，実験者が被験 者の目前約 $1 \mathrm{~m}$ の位置に立ち, あらかじめ用意した 解答と被験者の暗算結果を比較し, 間違つていた場 合は「違います，○○から始めてください」という ふうに，最後に正解した数を提示した。暗算課題開 始時に，できるかぎり速くなおかつ正確に課題を遂 行するように教示した.

\section{装置および指標}

日本電気三栄製ポリグラフシステム 360 を介して, 胸部誘導による心電困，橈骨動脈から導出された血 圧 (日本コーリン JENTOW 7700), 胸部インピーダ ンス（日本電気三栄 生体インピーダンス用増幅ユ ニット4134）を連続的に記録した。生体情報は 16bitの精度, $1000 \mathrm{~Hz}$ のサンプリング速度で $\mathrm{AD}$ 変 換した後, 計測用コンピュータのハードディスクに 記録した。

\section{データ処理}

LabVIEW 言語を用いたソフトウェアにより，心 電図波形から心拍間隔 (inter beat interval: IBI, ms) および心拍数 (heart rate: HR, bpm) を算出し, 血圧波 形から一拍毎に収縮期血圧 (systolic blood pressure: SBP, mmHg), 拡張期血圧 (diastolic blood pressure:
DBP, mmHg), 平均血圧 (mean blood pressure: MBP, $\mathrm{mmHg})$ を算出した。同様に，インピーダンスの一 次微分波形抢よび $\mathrm{ECG}$ 波形から一回心拍出量 (stroke volume: SV, ml) を算出した. また $\mathrm{HR} \times \mathrm{SV}$ により心拍出量 (cardiac output: CO, 1/min) を算出し, さらに MBP/COによって, 全末梢抵抗 (total peripheral resistance: TPR, dynes/s/cm-5) を算出した.

心理指標として GACLを用いた。 GACLは，全般 的活性 (GA), 脱活性 - 睡眠 (DS), 高活性 (HA), 全 般的脱活性 (GD)の4因子からなる. GACL は安静 期の直前および課題期の直後に施行した。後者では 課題中の気分を思い出しながら記入するよう教示を 行った。回答は，「全くそうではない」から「全く そのとおりだ」の7件法で行われた。

\section{結 果}

各生理指標に関し, 安静期, 課題期ともに 4 分間 の平均値を求め分析を行った。すべての生理指標に 関して, 群（サポートなし，サポートあり）×期間 (安静期, 課題期) の分散分析を行った。 その結果, HR，SV，CO，TPR，SBP，MBPに関しては期間の 主効果のみが有意であり（HR: $F(1,26)=61.52, p<.01$, $\mathrm{SV}: F(1,26)=87.94, p<.01, \quad \mathrm{CO}: F(1,26)=3.23, p<.10$, TPR: $F(1,26)=17.78, p<.01, \operatorname{SBP}: F(1,26)=58.12, p<.01$, MBP: $F(1,26)=62.62, p<.01)$, 群間の主効果は全ての 指標において有意ではなかった。安静期から課題期 への変化は, HR, CO, TPR, SBP, MBP は上昇方向, SVは下降方向であった。 DBPにおいてのみ, 期間 の主効果 $(F(1,26)=56.82, p<.01)$ に加え, 群 $\times$ 期間 の交互作用に有意な傾向 $(F(1,26)=3.34, p<0.1)$ が認 められた。単純主効果を求めたところ, 両群ともに 有意な DBPの上昇を認めた $(p<.001)$ 。安静期から 課題期にかけてのDBPの上昇はサポートなし群で $12.9 \mathrm{mmHg}$, サポートあり群で $7.9 \mathrm{mmHg}$ であった (Figure 1, Table 1参照).

心理指標に関しては，GACL を構成する各因子別 に合計点を算出し, 各々について生理指標と同様に 群（サポートなし, サポートあり） $\times$ 期間（安静期, 課題期）の分散分析を行つた。 その結果，GAに関 しては期間の主効果が有意であり $(F(1,26)=24.51, p<.01)$, 群 $\times$ 期間の交互作用に有意な傾向が認められた $(F(1,26)=9.76, p<.10)$. 単純主効果をもとめたところ, 


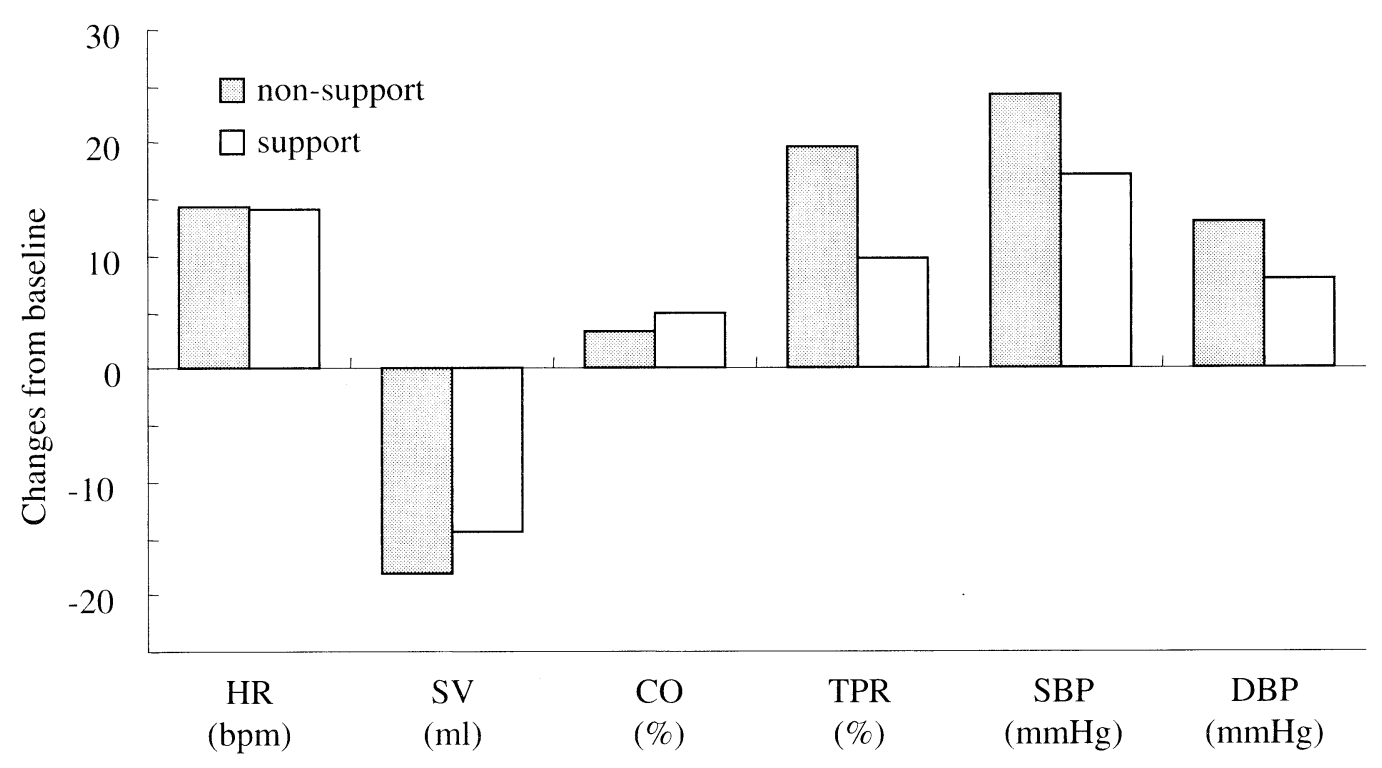

Figure 1. Cardiovascular changes from baseline.

Table 1. Cardiovascular activity during baseline and task period by group. Standard deviations are in parentheses.

\begin{tabular}{ccccc}
\hline & \multicolumn{2}{c}{ non-support } & \multicolumn{2}{c}{ support } \\
\hline & baseline & task & baseline & task \\
\hline HR & 67.2 & 81.5 & 68.7 & 82.9 \\
& $(7.9)$ & $(7.6)$ & $(10.5)$ & $(14.6)$ \\
SV & 114.9 & 96.9 & 107.3 & 92.9 \\
& $(32.0)$ & $(25.6)$ & $(27.6)$ & $(23.25)$ \\
CO & 7.5 & 7.8 & 7.3 & 7.7 \\
& $(1.9)$ & $(2.0)$ & $(2.1)$ & $(2.4)$ \\
TPR & 10.4 & 12.4 & 11.3 & 12.4 \\
& $(2.3)$ & $(3.3)$ & $(3.2)$ & $(3.5)$ \\
SBP & 114.8 & 139.0 & 116.1 & 133.2 \\
& $(8.4)$ & $(15.7)$ & $(8.4)$ & $(13.7)$ \\
DBP & 55.7 & 68.6 & 58.4 & 66.3 \\
& $(7.0)$ & $(6.9)$ & $(6.3)$ & $(7.9)$ \\
\hline
\end{tabular}

両群ともに $\mathrm{GA}$ の上昇が有意であり（ただしサポー トあり群は $p<.001$ であるのに対し, サポートなし 群は $p<.05)$, サポートあり群の GA は安静状態で既に サポートなし群のそれより低い傾向にあった $(p<.10)$. 結果として, GAの上昇量は, サポートあり群にお いて大きくなった。DSに関しては期間の主効果 $(F(1,26)=45.9, p<.01)$ および群 $\times$ 期間の交互作用 $(F(1,26)=8.02, p<.01)$ が有意であった. 単純主効果を
もとめたところ，両群ともにDS の下降が有意であ

り（ただし，サポートあり群は $p<.001$ であるのに対 し, サポートなし群は $p<.01)$, サポートあり群の DS は安静状態においてサポートなし群のそれより 高かった $(p<.05)$. 結果として, DS の下降はサポー トあり群において大きくなった，HA，GDに関して は期間の主効果のみが有意であり $(\mathrm{HA}: F(1,26)=33.65$, $p<.001, \mathrm{GD}: F(1,26)=59.01, p<.001), \mathrm{HA}$ は上昇, $\mathrm{GD}$ は下降方向の変化を示した. (Figure 2, Table 2参照). 課題成績は, 総回答数と誤答数に関して分析を行 つた。総回答数はサポートあり群で平均 75.7 問 $(S D=32.2)$, サポートなし群で平均 70.4 問 $(S D=20.4)$, 誤答数はサポートあり群で平均 4.6 問 $(S D=2.8)$, サ ポートなし群で平均 4.1 問 $(S D=2.3)$ であった. サポー トあり群とサポートなし群の総回答数, 誤答数の差 を $t$ 検定を用い検討した結果, 両群の成績に差は見 られなかった（総回答数に関しては $t(26)=.52, p=.61$, 誤答数に関しては, $t(26)=.51, p=.61)$.

\section{考 察}

生理指標に関しては, 先行研究と同様に支援的他 者の存在によるストレス反応軽減効果を認めた。し かし, その効果はDBPのみに有意差傾向を示すに とどまり, HR, SBPなどにも軽減を認めた先行研 究に比べると不明確であった. 明確な軽減効果を認 


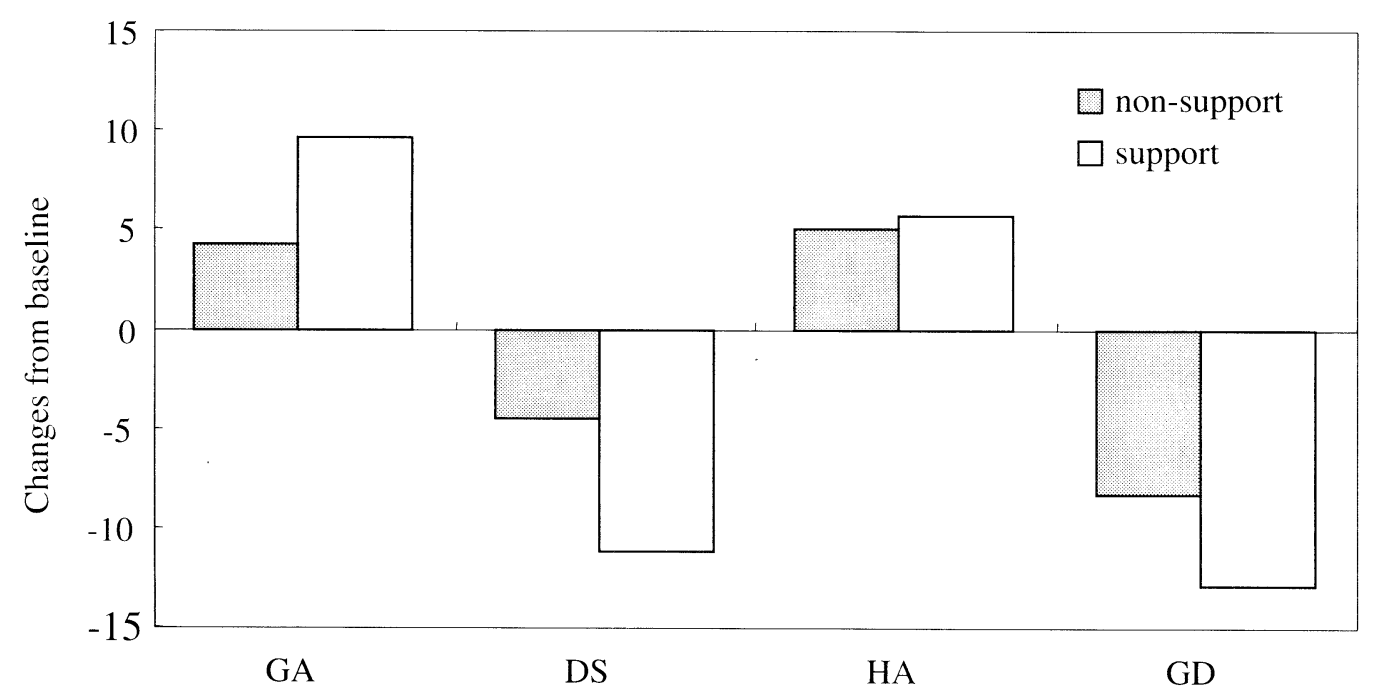

Figure 2. GACL score changes from baseline. GA, DS, HA, GD means general activation, deactivation-sleep, high activation, general deactivation respectively.

Table 2. Score of GACL during baseline and task period by group. Standard deviations are in parentheses.

\begin{tabular}{ccccc}
\hline & \multicolumn{2}{c}{ non-support } & \multicolumn{2}{c}{ support } \\
\hline & baseline & task & baseline & task \\
\hline GA & 16.6 & 20.9 & 13.3 & 22.9 \\
& $(6.0)$ & $(7.8)$ & $(4.2)$ & $(7.3)$ \\
DS & 14.0 & 9.4 & 19.1 & 7.9 \\
& $(4.9)$ & $(6.0)$ & $(6.4)$ & $(1.9)$ \\
HA & 16.0 & 21.0 & 14.4 & 20.1 \\
& $(5.4)$ & $(4.6)$ & $(5.0)$ & $(5.1)$ \\
GD & 19.1 & 10.9 & 22.4 & 9.5 \\
& $(7.6)$ & $(5.3)$ & $(5.8)$ & $(4.5)$ \\
\hline
\end{tabular}

めないケースとして, 同席する他者の評価的側面 が大きくなってしまうとサポート効果が得られな かったとの報告がある (Allen et al. 1991; Kors et al., 1997; Sheffield \& Carroll, 1996). しかし，本研究では Kamarck et al. (1990) にならい，支援的他者の評価的 側面が最小になるように状況設定を行い，同席した 他者が被験者の課題遂行の様子を察知できないよう に十分注意した。したがって，支援的他者の評価的 側面がストレス反応軽減効果を抑制したとは考えに くい.また，Kamarck et al. (1995) は，ストレス反応 軽減効果が明確に生じるのは, 課題負荷が高い場合 であり，負荷の低い状況では明確な効果が認められ
ないと報告した. しかし, 本研究における暗算課題 は, 平均約 $20 \mathrm{mmHg}$ の SBP 上昇を生じており, 先 行研究に比べ課題負荷が軽かったとは考えにくい. 他に, 敵意やシニシズムといった被験者本人の性格 傾向が，支援的他者によるストレス軽減効果を低減 させるとの報告 (Lepore, 1995) もあるが，これも本 研究には該当しない．本研究では，インピーダンス カーディオグラフィの電極を胸部に装着する都合上, 男性のみを被験者とした。しかし、ソーシャルサポー ト反応性に関する研究は，女性被験者のみを対象と したものが多数であり，男女混合の研究例はあって も男性のみを対象にした研究例は存在しない。この 背景には，社会的結びつきは女性においてより顕著 に観察されるという暗黙の了解があると思われる。 実際，支援的他者による心臟血管反応低減効果は女 性において顕著にみとめられ， (Linden, Chambers, Maurice, \& Lenz, 1993), 男性被験者では男性支援者 からのサポート効果が見られないとする研究結果も 報告されている (Glynn, Christenfeld, \& Gerin, 1999). したがって, 本研究において, ストレス反応軽減効 果が控えめなのは，被験者，支援者ともに男性を用 いた事によるものと考えるのが妥当であろう。血行 力学的反応に関しては, 平均值で見る限り安静期か ら課題期にかけてのCOの增大はサポートあり群の 方がやや大きく, 逆に TPR の増大はサポートなし 群のほうが大きいように見受けられる.SBP 上昇が 
心臓側血管側双方の機能六進を反映するのに対し, DBP 上昇は主として血管抵抗の増大を反映する事 が知られている。従って, サポート群において認め られた DBP 増大の抑制は，上記の TPRの差を反映 したものと考えられる。しかし，これらの変化に関 しては統計的に有意な群差を認めず, サポート効果 の生理学的媒介過程に関しては明確な結果が得られな かった. これら, 血行力学的反応の差異は, サポー トによる十分な血圧反応軽減効果の存在を前提に考 察されるべきものであり，本研究で得られた結果に よる検討には限界がある。これに関しては，女性の 助手を雇い電極を装着してもらう，インピーダンス カ一ディオグラフィ以外の方法で血行力学的反応を 検討する，等の工夫により女性被験者を使用し，十 分な血圧反応軽減効果を得た上で再度検討する必要 があるだろう。

心理指標に関しては,「いらいらした」「どきどき した」「緊迫した」などの質問項目からなるHA，「お ちついた」「くつろいだ」「ゆつたりした」などの質 問項目からなる GD には明確な群差が認められなか つた。この結果は, GACLにおける緊張覚醒におい ては，サポートの有無により差がなかった事を示す。 先に述べたように, 先行研究の多くが, 支援的他者 の存在は主観的ストレスや不快感情に差を生じない と報告した。 GACLの下位概念でストレスや不快感 情に関連するのはHAであるため, この点に関して は本研究においても同様の傾向を示す結果が得られ たと考えてよいだろう。一方，GA，DSにおいては 群×期間の交互作用を認めた。 GA は「活動的な」「精 力的な」「積極的な」など, DS は「とうとした」「ぼ んやりした」「だらだらした」などの質問項目から なり, サポートあり群はサポートなし群に比べ, GA 増大 DS 減少がより顕著であった。これは, GACLにおける, もうひとつの覚醒軸, すなわち工 ネルギー覚醒は支援的他者の存在により増大しやす くなる事を示す。この結果は, 支援的他者の存在は 主観的感情変化を介さず，より直接的に心臓血管系 に作用するとした Kamarck et al. (1990)の主張には 合致しない.むしろ Lepore (1998) が指摘したように, 支援的他者の存在により生じる肯定的感情の増大が, ストレス負荷時の心臓血管反応を軽減する可能性を 示唆するように思える。しかし, 畑山ら (1994) は,
GA とDS は刺激の賦活効果と密接に関連し, HA と GD は認知に基づく賦活効果に関連するとしており， 実際 GA, DS に含まれる質問項目は活動的な状態を あらわす語であり，肯定的感情語としては，やや不 十分な感は否めない. むしろ, 支援的他者の存在に よりもたらされた, なんらかの環境要因が, 課題に 対する動機付けを高め, エネルギ一覚醒の増大はそ れを反映したものとの解釈が妥当であるかもしれな い.ただし，GA，DSともにサポートの有無による 差が明確なのは, むしろ安静期である点には注意が 必要である.サポートなし群はサポートあり群に比 ベ, 安静状態で既に高い GA, 低いDS を報告して おり, サポートなし群は安静期に既にエネルギー覚 醒を高めてしまっていた可能性が考えられる.

生理指標との関係を考えるならば，より大きい工 ネルギー覚醒上昇を示したサポートあり群で, 血圧 反応がむしろ少ないのは一見逆説的に思える.この 結果は, 被験者の認知的評価を重要視する Blascovich グループの脅威/挑戦モデル（Blascovich \& Mendes, 2000）による解釈が適切であるかもしれ ない.このモデルでは, 環境要求が個人の対処資源 を上回った場合は認知的評価は脅威となり, そのよ うな場合は心拍出量, 血管抵抗ともに増大し, 血圧 上昇は顕著になると考える。それに対し, 環境要求 を個人の対処資源が上回った場合は，認知的評価は 挑戦となり, 心拍出量は増大するものの血管抵抗は 減少し，血圧上昇は控えめになるとする. エネルギー 覚醒の増大を, 認知的評価が挑戦になった結果であ ると考えるならば, DBP 増大の緩和は, 血管抵抗 の減少を反映したものと考えられるかもしれない. 統計的に有意な差は認められなかつたものの, サポー トあり群の TPR 増大は, サポートなし群に比べ半 分程度に抑えられている. Allen et al. (1991) は, 暗算 課題中の心臓血管反応を, 単独, 友人同席, ペット 同伴の 3 条件で比較し, ペット同伴時にのみサポー 卜効果を見出した。この結果に対し, Blascovich \& Mendes (2000) は, ペットの存在が状況の不確実性 評価を抑制し, Bowlby（1988）のアタッチメント理 論で述べられる安全避難所のような環境の作成に一 役買っていると述べている，彼らの理論に従えば, 不確実性の抑制は環境要求を減少させ，相対的に対 処資源の有効性を増し, 結果として認知的評価を挑 
戦方向に変化させるはずである。実際に, Allen et al. (2002) では, ペットの存在が認知的評価を挑戦 に変化させうる事が報告された。ただしこれらの研 究ではへモダイナミクスが調査されていないため, 本研究と類似した心臓血管反応が生じていたかは明 らかではない.

実験操作により生じる認知的過程は，実際には大 きな個人差があるものと思われる。しかし，そのよ うな内的過程の差異が心臟血管反応に与える影響は, いままで十分に検討されて来たとは言えない。冒頭 で紹介したLacey \& Laceyの環境の取り入れ/拒否 モデル, Obristの能動/受動対処モデルは, 主とし て刺激条件の違いから反応を説明しようとするもの であり、このような視点により本研究において得ら れた結果を説明するのは難しい。これまで, 競争状 況や評価状況における心臓血管反応を検討してきた が,これらの結果についてもまた同様である（長 野, 2004; 長野, 2005)。評価状況とサポート状況の対 比は，他者をどのように認知するかによってその心 臓血管反応への影響が劇的に変化する事を意味する. これは認知的過程が間違いなく心臓血管反応の重要 な決定因となる事，そしてその過程は対人的要因に 大きく影響を受ける事を端的に示していると言える だろう。

\section{引用文献}

Allen, K., Blascovich, J., \& Mendes, W. B. 2002 Cardiovascular reactivity and the presence of pets, friends, and spouses: the truth about cats and dogs. Psychosomatic Medicine, 64, 727-739.

Allen, K. M., Blascovich, J., Tomaka, J., \& Kelsey, R. M. 1991 Presence of human friends and pet dogs as moderators of autonomic responses to stress in women. Journal of Personality and Social Psychology, 61, 582-589.

Blascovich, J., \& Mendes, W. 2000 Challenge and threat appraisals: The role of affective cues. In J. P. Forgas(Ed.), Feeling and thinking: The role of affect in social cognition. London: Cambridge University Press. pp. 59-82.

Blumenthal, J. A., Burg, M. M., Barefoot, J., Williams, R. B., Haney, T., \& Zimet, G. 1987 Social support, type A behavior, and coronary artery disease. Psychosomatic Medicine, 49, 331-340.

Bolger, N., DeLongis, A., Kesseler, R. C., \& Schilling, E. A. 1989 The effects of daily stress on negative mood. Journal of Personality and Social Psychology, 57, 808818.

Bowlby, J. 1988 A secure base: Parent-child attachment and healthy human development. New York: Basic Books.

Carroll, D., \& Sheffield, D. 1998 Social psychophysiology, social circumstances, and health. Annals of Behavioral Medicine, 20, 333-337.

Christenfeld, N., \& Gerin, W. 2000 Social support and cardiovascular reactivity. Biomedicine and Pharmacotherapy, 54, 251-257.

Edens, J. L., Larkin, K. T., \& Abel, J. L. 1992 The effect of social support and physical touch on cardiovascular reactions to mental stress. Journal of Psychosomatic Research, 36, 371-381.

Gerin, W., Pieper, C., Levy, R., \& Pickering, T. G. 1992 Social support in social interaction: a moderator of cardiovascular reactivity. Psychosomatic Medicine, 54, 324-336.

Glynn, L. M., Christenfeld, N., \& Gerin, W. 1999 Gender, social support, and cardiovascular responses to stress. Psychosomatic Medicine, 61, 234-242.

畑山俊輝 - Gerrit Antonides - 松岡和生 - 丸山欣哉 1994 アラウザルチェックリスト (GACL) から見 た顔のマッサージの心理的緊張低減効果 応用心 理学研究, 19, 11-19.

House, J. S., Landis, K. R., \& Umberson, D. 1988 Social relationships and health. Science, 241, 540-545.

House, J. S., Robbins, C., \& Metzner, H. L. 1982 The association of social relationships and activities with mortality: prospective evidence from the Tecumseh Community Health Study. American Journal of Epidemiology, 116, 123-140.

Kamarck, T. W., Annunziato, B., \& Amateau, L. M. 1995 Affiliation moderates the effects of social threat on stress-related cardiovascular responses: boundary conditions for a laboratory model of social support. Psychosomatic Medicine, 57, 183-194. 
Kamarck, T. W., \& Lovallo, W. R. 2003 Cardiovascular reactivity to psychological challenge: conceptual and measurement considerations. Psychosomatic Medicine, 65, 9-21.

Kamarck, T. W., Manuck, S. B., \& Jennings, J. R. 1990 Social support reduces cardiovascular reactivity to psychological challenge: a laboratory model. Psychosomatic Medicine, 52, 42-58.

Kors, D. J., Linden, W., \& Gerin, W. 1997 Evaluation interferes with social support: Effects on cardiovascular stress reactivity in women. Journal of Social and Clinical Psychology, 16, 1-23.

Lacey, B. C., \& Lacey, J. I. 1974 Studies of heart rate and other bodily processes in sensorimotor behavior. In P. A. Obrist, A. H. Black, J. Brener and L. V. DiCara (Eds.), Cardiovascular Psychophysiology. Chicago: Aldine. pp. 538-564.

Lepore, S. J. 1995 Cynicism, social support, and cardiovascular reactivity. Health Psychology, 14, 210216.

Lepore, S. J. 1998 Problems and prospects for the social support-reactivity hypothesis. Annals of Behavioral Medicine, 20, 257-269.

Lepore, S. J., Allen, K. A., \& Evans, G. W. 1993 Social support lowers cardiovascular reactivity to an acute stressor. Psychosomatic Medicine, 55, 518-524.

Linden, W., Chambers, L., Maurice, J., \& Lenz, J. W. 1993 Sex differences in social support, self-deception, hostility, and ambulatory cardiovascular activity. Health Psychology, 12, 376-380.

Linden, W., Rutledge, T., \& Con, A. 1998 A case for the usefulness of laboratory social stressors. Annals of Behavioral Medicine, 20, 310-316.

長野祐一郎 2002 能動的対処は圧反射感度を抑制 するか 生理心理学と精神生理学, 20, 1-8.

長野祐一郎 2004 競争型鏡映描写課題における心臟 血管反応 生理心理学と精神生理学, 22, 237-246. 長野祐一郎 2005 評価的観察が精神課題遂行中の心 臓血管反応に与える影響 心理学研究, 76, 252259.

Obrist, P. A. 1981 Cardiovascular psychophysiology:A Perspective. New York: Plenum Press.
Schwartz, A. R., Gerin, W., Davidson, K. W., Pickering, T. G., Brosschot, J. F., Thayer, J. F., Christenfeld, N., \& Linden, W. 2003 Toward a causal model of cardiovascular responses to stress and the development of cardiovascular disease. Psychosomatic Medicine, 65, 22-35.

Seeman, T. E., \& Syme, S. L. 1987 Social networks and coronary artery disease: a comparison of the structure and function of social relations as predictors of disease. Psychosomatic Medicine, 49, 341-354.

Sheffield, D., \& Carroll, D. 1996 Task-induced cardio vascular activity and the presence of a supportive or undermining other. Psychology and Health, 11, 583591.

Smith, T. W., \& Gerin W. 1998 The social psychophysiology of cardiovascular response: An introduction to the special issue. Annals of Behavioral Medicine, 20, 243-246.

Smith, T. W., Nealey, J. B., Kircher, J. C., \& Limon, J. P. 1997 Social determinants of cardiovascular reactivity: effects of incentive to exert influence and evaluative threat. Psychophysiology, 34, 65-73.

Uchino, B. N., Cacioppo, J. T., \& Kiecolt-Glaser, J. K. 1996 The relationship between social support and physiological processes: a review with emphasis on underlying mechanisms and implications for health. Psychological Bulletin, 119, 488-531.

Waldstein, S. R., Neumann, S. A., Burns, H. O., \& Maier, K. J. 1998 Role-played interpersonal interaction: ecological validity and cardiovascular reactivity. Annals of Behavioral Medicine, 20, 302-309.

Williams, R. B. 1986 Patterns of reactivity and stress. In K. A. Matthews, S. M. Weiss, T. Detre, T. M. Demobroski, B.Falkner, S. B., Manuck \& R. B. Williams (Eds.), Handbook of stress, reactivity, and cardiovascular disease. New York : John Wiley \& Sons. pp.109-125.

Wright, R. A., Dill, J. C., Geen, R. G., \& Anderson, C. A. 1998 Social evaluation influence on cardiovascular response to a fixed behavioral challenge: effects across a range of difficulty levels. Annals of Behavioral Medicine, 20, 277-285. 